\title{
PENGOLAHAN KANDUNGAN COD LIMBAH CAIR PABRIK KELAPA SAWIT OLEH TYPHA LATIFOLIA DENGAN METODE FITOREMEDIASI
}

\author{
Shinta Elystia, Aryo Sasmita, Purwanti \\ Laboratorium Pengendalian dan Pencegahan Pencemaran Lingkungan \\ Program Studi S1 Teknik Lingkungan, Fakultas Teknik Universitas Riau \\ Email: shintaelystia@yahoo.com
}

\begin{abstract}
ABSTRAK
Limbah cair pabrik kelapa sawit meskipun sudah diolah, limbah yang dibuang ke sungai masih belum memenuhi baku mutu yang ditetapkan. Untuk itu diperlukan alternatif pengolahan secara alami dengan metode fitoremediasi yang memanfaatkan tanaman Typa Latifolia. Fitoremediasi merupakan salah satu teknologi yang secara biologi yang memanfaatkan tumbuhan atau mikroorganisme yang dapatberasosiasi untuk mengurangi polutan lingkungan baik pada air, tanah dan udara yang diakibatkan oleh logam atau bahan organik. Penelitian bertujuan untuk melihat kemampuan sistem fitoremediasi dengan tanaman Typa Latifolia dalam mengolah kandungan COD dengan variasi kerapatan tanaman, kadar limbah, dan waktu tinggal. Pada penelitian ini digunakan bak plastik ukuran 50cm $x 36 \mathrm{~cm}$ $x 31 \mathrm{~cm}$, media tanah dengan ketebalan $10 \mathrm{~cm}$, media pasir ketebalan $5 \mathrm{~cm}$, dan media kerikil setebal $5 \mathrm{~cm}$ dengan variasi kerapatan tanaman Typha latifolia $\left(0,5 \mathrm{~g} / \mathrm{cm}^{2} ; 0,75 \mathrm{~g} / \mathrm{cm}^{2} ; \mathrm{dan} 1 \mathrm{~g} / \mathrm{cm}^{2}\right)$, variasi kadar limbah cair kelapa sawit (20\%; 60\%; dan 100\%), dan variasi waktu tinggal (5 hari dan 9 hari). Parameter yang dianalisis adalah COD, dengan konsentrasi sebelum pengolahan sebesar 2820-3980 mg/l, sedangkan setelah diolah konsentrasinya turun menjadi 720-2720 mg/l pada hari ke 5 dan 80-2340 mg/l pada hari ke 9. Hasil ini menunjukkan bahwa metode fitoremediasi menggunakan Typha latifolia mampu menyisihkan konsentrasi COD limbah cair pabrik kelapa sawit. Secara umum, variasi kerapatan tanaman, kadar limbah, dan waktu tinggal memberikan pengaruh yang signifikan untuk penurunan COD. Kerapatan tanaman $1 \mathrm{~g} / \mathrm{cm}^{2}$, kadar limbah 20\%, dan waktu tinggal 9 hari memberikan efisiensi tertinggi untuk masing-masing parameter pencemar. Secara keseluruhan efisiensi penyisihan BOD, COD, dan TSS yang diperoleh pada penelitian ini pada hari ke 5 berkisar antara 31,66-74,65\% dan pada hari ke 9 berkisar antara $41,21-97,18 \%$.
\end{abstract}

Kata Kunci: Limbah Cair Pabrik Kelapa Sawit, Fitoremediasi, Typha latifolia, Kerapatan Tanaman, Kadar Limbah

\begin{abstract}
Palm oil mill wastewater still does not meet the quality standards. It is necessary to find another alternative treatment to reduce the contaminant, such as phytoremediation by using Typa latifolia. The study aims to investigate the ability of phytoremediation systems with Typa latifolia plants to reduce COD using levels of waste, and the residence time as parameters. This research used $50 \mathrm{~cm} \times 36 \mathrm{~cm} \times 31 \mathrm{~cm}$ plastic tube, $10 \mathrm{~cm}$ soil thickness, $5 \mathrm{~cm}$ sand and gravel with plant density variations Typha latifolia $\left(0,5 \mathrm{~g} / \mathrm{cm}^{2} ; 0,75 \mathrm{~g} / \mathrm{cm}^{2}\right.$, and $\left.1 \mathrm{~g} / \mathrm{cm}^{2}\right)$, palm oil concentration in liquid waste $(20 \%, 60 \%$ and $100 \%)$, and the variation of the residence time (5 days and 9 days). COD value before treatment was 2820-3980 mg/l, this value reduced 720-2720 $\mathrm{mg} / \mathrm{l}$, on day 5 and $80-2340 \mathrm{mg} / \mathrm{l}$, on day 9 These results indicate that the phytoremediation using Typha latifolia was is to remove COD, from palm oil mill effluent. In general, variations in the density of plants, waste levels, and residence time have a significant influence, this has evidenced by the removal. $1 \mathrm{~g} / \mathrm{cm}^{2}$ plant density, 20\% waste concentration, and 9 days residence time provide the highest efficiency for each pollutant parameters. Overall removal efficiency of BOD, COD, and TSS in this study were consecutively on day 5 ranged from 31,66 to 74,65\%, and on day 9 ranged from, from 41,21 to 97,18\%.
\end{abstract}

Keywords: Palm Oil Mill Waste Water, Phytoremediation, Typha latifolia, Plant Density, Waste Levels 


\section{PENDAHULUAN}

Perkebunan kelapa sawit Provinsi Riau memiliki areal yang terbesar di Indonesia, meliputi 2,2 juta hektar atau 25 persen dari total luas perkebunan kelapa sawit Indonesia. Produksi CPO Provinsi Riau tercatat sebesar 7.045.632 ton dan Palm Kernel Oil (PKO) tercatat 1.761 .408 ton (Frislidia, 2013).

Seiring dengan berkembangnya industri kelapa sawit, semakin banyak pula limbah cair yang dihasilkan. Untuk itu perlu dilakukan pengolahan limbah cair kelapa sawit karena apabila limbah langsung dibuang ke lingkungan akan mengakibatkan penurunan kualitas lingkungan.

Pengolahan limbah pada PKS meliputi beberapa tahapan fisika, kimia, dan biologi. Meskipun sudah mengalami pengolahan, limbah yang dibuang ke sungai masih belum memenuhi baku mutu yang ditetapkan (Raharjo, 2009). Hal ini terjadi karena IPAL belum berfungsi dengan baik (Azwir, 2006). Oleh karena itu, diperlukan suatu sistem pengolahan limbah yang dapat memberikan hasil yang optimal dalam mengolah dan mengendalikan limbah sehingga dampaknya terhadap lingkungan dapat dikurangi.

Looker (1998) dalam Volkman (2003) menyatakan dalam dua dekade ke depan penerapan pengolahan limbah sebaiknya mengimplementasikan pengolahan dengan biaya rendah. Untuk mencapai tujuan tersebut, pengolahan limbah dengan prinsip ekologis direkomendasikan dengan menggunakan sistem pengolahan siklus tertutup dimana limbah yang ada dimanfaatkan secara optimal dalam sistem. Salah satu alternatif sistem pengolahan air limbah tersebut adalah fitoremediasi (Evasari, 2012).

Fitoremediasi adalah teknologi proses dengan menggunakan vegetasi (tanaman) untuk menghilangkan dan memperbaiki kondisi tanah, sludge, kolam, sungai dari kontaminan (Melithia dkk, 1996). Metode fitoremediasi berkembang pesat karena metoda ini mempunyai beberapa keunggulan diantaranya relatif murah bila dibandingkan dengan metoda konvensional biaya dapat dihemat sebesar 75-85\% (Surakusumah, 2010).
Teknologi fitoremediasi sudah banyak digunakan di negara maju seperti Amerika, Perancis, Inggris, Denmark, Jerman, Jepang, dan lain-lain dengan menggunakan berbagai jenis tanaman sebagai pengolah limbah yang bersimbiosis dengan bakteri, jamur, dan organisme lainnya. Secara umum, proses pengolahan air limbah organik pada sistem fitoremediasi sangat sederhana yaitu bahan pencemar didegradasi oleh bakteri, jamur, dan organisme lainnya sehingga menghasilkan zat anorganik dengan struktur lebih sederhana. Hasil penguraian zat organik menjadi anorganik tersebut diabsorpsi oleh tanaman dan melalui proses metabolisme digunakan untuk pertumbuhan organnya seperti : akar, batang, daun, bunga, dan buah (Evasari, 2012).

Berdasarkan rata-rata kondisi iklim Indonesia yang potensial untuk mendukung pertumbuhan dan transpirasi tanaman sepanjang tahun, maka pengolahan air limbah menggunakan sistem fitoremediasi diperkirakan dapat berjalan dengan optimal. Di Indonesia sendiri penelitian mengenai pengolahan limbah cair kelapa sawit dengan metode fitoremediasi sudah mulai dilakukan. Berdasarkan hasil penelitian Avlenda (2009), disimpulkan bahwa teknik fitoremediasi menggunakan genjer dan kangkung dapat dikembangkan untuk pengolahan limbah cair pabrik kelapa sawit. Prediksi waktu yang paling singkat untuk menurunkan nilai BOD, COD dan TSS hingga mencapai BML diperoleh dengan menggunakan genjer pada kadar limbah $20 \%$.

Typha latifolia telah diketahui di berbagai negara sebagai aset berharga dalam metode penjernihan air yang murah dan efektif. Berdasarkan morfologi tanaman Typha latifolia sangat cocok untuk pengolahan dengan sistem fitoremediasi. Typha latifolia memiliki sistem perakaran yang banyak dan kuat yang dapat membantu menstabilisasi sungai dengan menyerap zat organik dan membatasi erosi tanah. (Evasari, 2012). Di Portugal, Calheiros, et al (2008) melakukan penelitian dengan menggunakan Typha latifolia pada lahan basah buatan untuk mengolah limbah cair industri penyamakan kulit didapatkan hasil removal BOD sebesar $69 \%$ dan removal COD sebesar $82 \%$. 
Tumbuhan Typha (cattails) merupakan vegetasi lahan basah yang memiliki banyak manfaat. Berdasarkan laporan kajian FAO (Food and Agriculture Organization, 2007) tentang sistem pengolahan limbah, bahwa Typha latifolia berpotensi mengolah limbah buangan industri. $T$. latifolia mampu mereduksi kandungan logam (Bareen \& Khilji, 2008), menurunkan beban BOD, COD, dan TSS limbah cair domestik (Hidayah \& Aditya, 2010).

Berdasarkan hal diatas, maka dilakukan penelitian pengolahan limbah cair kelapa sawit dengan metode fitoremediasi menggunakan tanaman Typha latifolia untuk mengurangi beban pencemar ke lingkungan dilihat dari parameter COD dengan variasi kerapatan tanaman, kadar limbah dan waktu tinggal. Dimana diharapkan semakin rapat tanaman Typha latifolia semakin banyak pula polutan yang diserap oleh akar tanaman Typha latifolia sehingga diharapkan kemampuan penyisihan akan semakin besar. Hal yang sama juga terjadi pada kadar limbah dan waktu tinggal. Semakin kecil kadar limbah maka akan semakin besar kemampuan penyisihannya dan semakin lama waktu tinggal maka semakin besar kemampuan penyisihan polutan

\section{METODOLOGI}

\section{Bahan}

1. Limbah cair yang digunakan dalam penelitian ini adalah limbah cair yang berasal dari kolam pengolahan 4 PT. Perkebunan Nusantara V PKS Sei Buatan.

2. Media lahan basah

Sebagai media lahan basah digunakan tanah setebal $10 \mathrm{~cm}$, pasir setebal $5 \mathrm{~cm}$, dan kerikil setebal $5 \mathrm{~cm}$.

3. Tanaman

Tanaman yang digunakan dalam penelitian ini adalah Typha latifolia sebagai agen fitoremediasi.

\section{Alat dan Instrumentasi}

Alat-alat yang digunakan dalam penelitian ini adalah:

1. Reaktor

Reaktor berupa bak plastik ukuran $50 \mathrm{~cm} \times 36 \mathrm{~cm} \times 31 \mathrm{~cm}$.
2. Bak penampung influen

Bak penampung influen berupa ember yang terbuat dari plastik dengan ukuran volume 20 liter.

3. Selang Plastik

Selang plastik berfungsi mengalirkan limbah cair dari bak penampung influen ke reaktor. Diameter selang plastik yang digunakan adalah $1 / 2$ inchi dengan panjang $100 \mathrm{~cm}$.

4. Sambungan Pipa

Diameter sambungan pipa inlet dan sambungan pipa outlet yang digunakan yaitu sebesar $1 / 2$ inchi.

5. Pipa drain Ukuran pipa drain adalah $1 / 4$ inchi.

6. Kran air,

Berfungsi untuk membuka dan menutup aliran limbah cair.

7. Bak penampung efluen

Berfungsi untuk menampung efluen hasil olahan reaktor limbah cair pabrik kelapa sawit berukuran 5 liter.

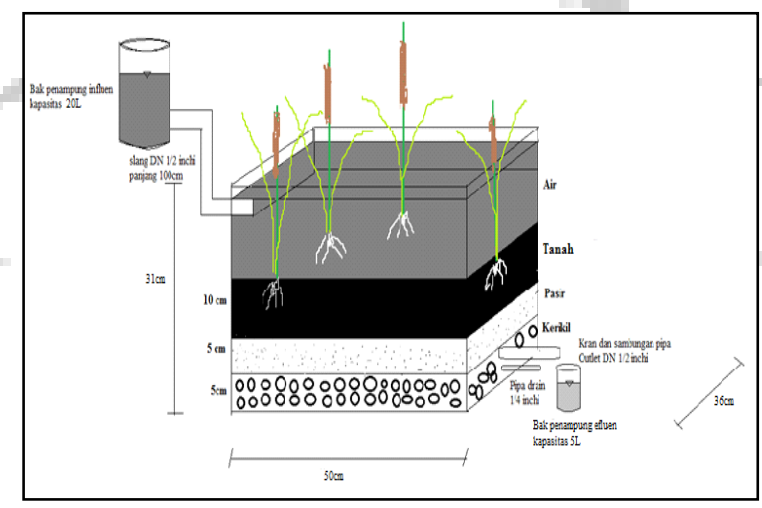

\section{Gambar 1. Instalasi Reaktor Fitoremediasi Menggunakan Tanaman Typha latifolia}

\section{Variabel Penelitian}

Variabel bebas pada penelitian ini adalah variasi kerapatan tanaman Typha latifolia $\left(0,5 \mathrm{~g} / \mathrm{cm}^{2}, 0,75 \mathrm{~g} / \mathrm{cm}^{2}\right.$, dan $\left.1 \mathrm{~g} / \mathrm{cm}^{2}\right)$, variasi kadar limbah cair pabrik kelapa sawit $(20 \%$, $60 \%$, dan $100 \%$ ), dan variasi waktu tinggal (5 hari dan 9 hari).

Variabel tetap pada penelitian ini adalah metode fitoremediasi dengan bak plastik ukuran $50 \mathrm{~cm}$ x $36 \mathrm{~cm}$ x $31 \mathrm{~cm}$ menggunakan media tanah setebal $10 \mathrm{~cm}$, pasir setebal $5 \mathrm{~cm}$, dan kerikil setebal $5 \mathrm{~cm}$ 


\section{Prosedur Penelitian}

\section{Percobaan Pendahuluan}

A. Pengambilan Sampel

Metode pengambilan sampel dilakukan secara grab sampel yaitu pengambilan sampel dilakukan sebanyak 1 kali. Pada pabrik kelapa sawit PT. Perkebunan Nusantara V Sei Buatan ini mempunyai 5 kolam pengolahan anaerobic. Dimana sampel yang akan diuji diambil secara acak dari kolam pengolahan anaerobic 4, yang kemudian sampel dikompositkan menjadi satu. Pengambilan sampel dilakukan di kolam anaerobic ke 4 karena kolam ini merupakan kolam pengolahan terakhir sebelum limbah dialirkan ke areal perkebunan. Pengambilan sampel dilakukan pada pagi hari sekitar pukul 10 pagi dimana pabrik sedang melakukan pengolahan. Selanjutnya sampel dimasukkan ke dalam dirigen sampel untuk dilakukan pengamatan eksitu yang akan di analisa di Laboratorium Pencegahan Pencemaran Lingkungan Fakultas Teknik Universitas Riau.

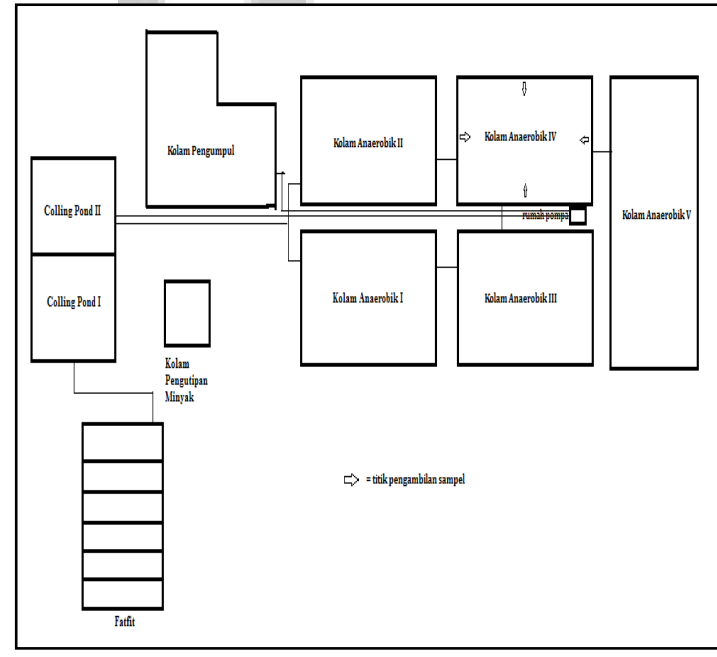

Gambar 2. Lokasi Pengambilan Sampel

\section{B. Aklimatisasi Typha latifolia}

Tanaman Typha latifolia diaklimatisasi dengan cara ditanam pada ember yang berisi tanah, pasir, dan kerikil \pm selama 1 minggu. Tujuan aklimatisasi tanaman Typha latifolia pada reaktor adalah untuk menstabilkan dan menyesuaikan keadaan lingkungan reaktor untuk memulai proses fitoremediasi pada limbah cair pabrik kelapa sawit.

\section{Percobaan Utama}

Sampel yang digunakan dalam penelitian ini adalah limbah cair pabrik kelapa sawit PT. Perkebunan Nusantara V Sei Buatan. Sampel ini merupakan limbah cair dari kolam anaerobik ke 4 yang mempunyai kadar efisiensi penyisihan parameter pencemar yang belum sesuai dengan batas baku mutu untuk di buang ke badan air.

Analisis parameter pencemar limbah cair yang dilakukan di laboratorium adalah analisis terhadap parameter COD dengan menggunakan metode yang mengacu pada SNI 6989.2:2009 metode Refluks Tertutup secara Spektrofotometri.

\section{Analisis Hasil Percobaan}

Data yang didapat merupakan hasil analisis sampel limbah cair pabrik kelapa sawit dari PT. Perkebunan Nusantara V-PKS Sei Buatan sebelum dan setelah diproses dengan fitoremediasi menggunakan Typha latifolia, untuk menentukan efisiensi penyisihan tergantung dari karakteristik COD yang terkandung dalam sampel. Efisiensi unit ditunjukan dengan persentase reduksi pencemar. Perhitungan persentase sebagai berikut :

\section{Efisiensi $(\%)=\underline{\text { Cin }- \text { Cef }} \times 100 \%$ Cin}

Dimana :

Cin $=$ Konsentrasi awal

Cef $=$ Konsentrasi akhir

Selain menentukan efisiensi reduksi COD yang terkandung dalam sampel, juga ditampilkan hubungan antara efisiensi reduksi pencemar dengan variasi jarak tanam Typha latifolia, variasi kadar limbah cair kelapa sawit, dan variasi waktu tinggal dalam bentuk grafik. Kemudian hasil air olahan dibandingkan dengan baku mutu, yaitu Surat Keputusan Menteri Lingkungan Hidup Nomor 51 Tahun 1995 tentang baku mutu limbah cair

\section{HASIL DAN PEMBAHASAN}

Karakteristik influen limbah cair pabrik kelapa sawit meliputi pengujian BOD, COD, 
dan TSS dari kolam pengolahan anaerobic 4 adalah sebagai berikut.

Tabel 1. Analisis Karakteristik Limbah Cair Kelapa Sawit

\begin{tabular}{lccc}
\hline Parameter & Satuan & $\begin{array}{c}\text { Laku } \\
\text { Mutu }\end{array}$ & $\begin{array}{c}\text { Limbah } \\
\text { Cair } \\
\text { Kelapa } \\
\text { Sawit }^{2}\end{array}$ \\
\hline $\mathrm{BOD}$ & $\mathrm{mg} / \mathrm{l}$ & 250 & 5544 \\
\hline $\mathrm{COD}$ & $\mathrm{mg} / \mathrm{l}$ & 500 & 3980 \\
\hline $\mathrm{TSS}$ & $\mathrm{mg} / \mathrm{l}$ & 300 & 20933 \\
$\begin{array}{l}\text { Sumber: } \\
\text { 1995 }{ }^{2} \text { Hasil Menteri Lenelitian }\end{array}$
\end{tabular}

Berdasarkan data yang tertera dalam Tabel 1, kualitas limbah cair pabrik kelapa sawit harus dilakukan pengolahan sebelum dibuang ke badan air, karena konsentrasi tersebut masih di atas baku mutu yang di perbolehkan sesuai dengan surat keputusan Menteri Negara Lingkungan Hidup No. 51 Tahun 1995. Dengan adanya pemanfaatan tanaman jenis Typha latifolia dalam proses fitoremediasi diharapkan dapat menurunkan konsentrasi COD yang terkandung di dalam limbah cair pabrik kelapa sawit PTPN VPKS Sei Buatan.

\section{Percobaan Utama}

Adapun hasil pengujian efluen limbah cair pabrik kelapa sawit setelah diolah dengan tanaman Typha latifolia dengan metode fitoremediasi adalah sebagai berikut.

Dari Tabel 2 dan 3 menunjukkan bahwa adanya pengaruh waktu tinggal yang mempengaruhi efisiensi penyisihan COD. Efisiensi penyisihan bergantung pada konsentrasi dan lamanya waktu penahanan di dalam reaktor. Tingkat permeabilitas media tersebut sangat berpengaruh terhadap waktu detensi air limbah, dimana waktu detensi yang cukup akan memberikan kesempatan kontak antara mikroorganisme dengan air limbah (Supradata, 2005), sehingga semakin lama waktu tinggal maka semakin tinggi efisiensi penyisihan pencemarnya.
Tabel 2. Hasil Uji Efluen LCPKS Hari Ke-5

\begin{tabular}{ccccc}
\hline $\begin{array}{c}\text { Kadar } \\
\text { Limbah } \\
(\%)\end{array}$ & $\begin{array}{c}\text { Kerapatan } \\
\text { Tanaman } \\
\left(\mathbf{g} / \mathbf{c m}^{2}\right)\end{array}$ & \multicolumn{2}{c}{$\begin{array}{c}\text { Hasil Uji Sampel } \\
\text { COD (mg/l) }\end{array}$} & $\begin{array}{c}\text { Efisiensi } \\
\mathbf{( \% )}\end{array}$ \\
\hline 20 & 0 & 2840 & 1600 & 43,66 \\
\cline { 2 - 4 } & 0,5 & 2800 & 880 & 68,57 \\
\cline { 2 - 4 } & 0,75 & 2820 & 820 & 70,92 \\
\cline { 2 - 4 } & 1 & 2840 & 720 & 74,65 \\
\hline 60 & 0 & 3080 & 1880 & 38,96 \\
\cline { 2 - 4 } & 0,5 & 3100 & 1240 & 60 \\
\hline 100 & 0,75 & 3060 & 1160 & 62,09 \\
\cline { 2 - 4 } & 1 & 3080 & 1060 & 65,58 \\
\hline & 0 & 3980 & 2720 & 31,66 \\
\hline & 0,5 & 3960 & 1680 & 57,58 \\
\hline & 0,75 & 3940 & 1620 & 58,88 \\
\hline
\end{tabular}

Tabel 3 Hasil Uji Efluen Limbah Cair Pabrik Kelapa Sawit Hari ke-9

\begin{tabular}{|c|c|c|c|c|}
\hline \multirow{2}{*}{$\begin{array}{c}\text { Kadar } \\
\text { Limbah } \\
(\%)\end{array}$} & \multirow{2}{*}{$\begin{array}{c}\text { Kerapatan } \\
\text { Tanaman } \\
\left(\mathrm{g} / \mathrm{cm}^{2}\right)\end{array}$} & \multicolumn{2}{|c|}{$\begin{array}{c}\text { Hasil Uji Sampel } \\
\text { COD (mg/l) } \\
\end{array}$} & \multirow{2}{*}{$\begin{array}{l}\text { Efisiensi } \\
\quad(\%)\end{array}$} \\
\hline & & Influen & Efluen & \\
\hline \multirow[t]{4}{*}{20} & 0 & 2840 & 1280 & 54,93 \\
\hline & 0,5 & 2800 & 200 & 92,86 \\
\hline & 0,75 & 2820 & 160 & 94,33 \\
\hline & 1 & 2840 & 80 & 97,18 \\
\hline \multirow[t]{4}{*}{60} & 0 & 3080 & 1620 & 47,40 \\
\hline & 0,5 & 3100 & 660 & 78,71 \\
\hline & 0,75 & 3060 & 600 & 80,39 \\
\hline & 1 & 3080 & 480 & 84,42 \\
\hline \multirow[t]{4}{*}{100} & 0 & 3980 & 2340 & 41,21 \\
\hline & 0,5 & 3960 & 1000 & 74,75 \\
\hline & 0,75 & 3940 & 860 & 78,17 \\
\hline & 1 & 3960 & 720 & 81,82 \\
\hline
\end{tabular}

Tabel di atas menunjukkan semakin lama waktu tinggalnya di dalam reaktor maka semakin efektif penurunan konsentrasi CODnya. Dengan semakin lamanya wkatu kontak antar limbah cair dengan reaktor fitoremediasi, maka mekanisme kerja mikroorganisme semakin lama, proses dekomposisi atau degradasi yang terjadi berlangsung sempurna. Dan kemampuan tanaman menyerap material organik dari limbah memiliki waktu yang cukup. 


\section{Pengaruh Variasi Perlakuan Terhadap Efisiensi Penyisihan COD}

Hasil penelitian penyisihan konsentrasi COD pada sampel limbah cair pabrik kelapa sawit dengan metode fitoremediasi menggunakan Typha latifolia dengan variasi kerapatan tanaman, kadar limbah, dan waktu tinggal adalah sebagai berikut.

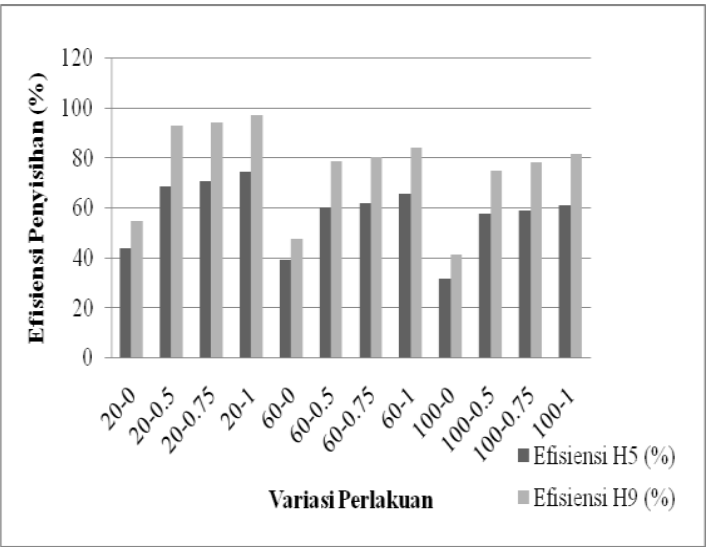

\section{Gambar 3 Pengaruh Variasi Perlakuan Terhadap Efisiensi Penyisihan COD}

Ket:

20,60,100 = Kadar Limbah

0;0,5;0,75;1= Kerapatan Tanaman

\section{Pengaruh Kerapatan Tanaman}

Berdasarkan Gambar 3 maka didapatkan bahwa efisiensi penyisihan konsentrasi COD tertinggi adalah $97,18 \%$ dan terendah adalah $31,66 \%$. Efisiensi tertinggi terjadi di bak reaktor dengan kerapatan tanaman $1 \mathrm{~g} / \mathrm{cm}^{2}$ dan kadar limbah 20\% pada waktu tinggal 9 hari. Kemampuan penyisihan kandungan COD meningkat pada proses lamanya waktu tinggal, Semakin rapat tanaman dan kadar limbah semakin rendah. Berdasarkan teori Typha latifolia memiliki sistem perakaran yang banyak, dengan semakin banyaknya akar yang dimiliki tanaman Typha latifolia dapat menyerap semakin banyak material organik yang terdapat dalam air limbah cair kelapa sawit. Semakin banyak Typa latifolia yang digunakan maka penyerapan bahan organik pun akan semakin banyak pula sehingga oksigen dalam limbah tersebut bertambah sebagai hasil dari fotosintesis tanaman tersebut. Aktivitas fotosintesis yang tinggi, akan menghasilkan oksigen yang tinggi pula sehingga oksigen terlarut dalam limbah cair akan meningkat, Typha latifolia mensuplai oksigen ke dalam air limbah melalui akar dan menambah jumlah oksigen terlarut dalam air limbah sehingga akan memacu kerja mikroorganisme dalam menguraikan senyawa-senyawa pencemar (Fardiaz, 1992). Oksigen ini akan digunakan oleh mikroorganisme untuk mendegradasi bahan organik menjadi bahan anorganik, seperti $\mathrm{NO}_{3}^{-}, \mathrm{NO}_{2}^{-}, \mathrm{H}_{2} \mathrm{O}$ dan lainnya.

Typha latifolia akan menyerap unsur-unsur hara yang larut dalam air melalui akarnya yang serabut. Penyerapan tersebut dilakukan oleh akar tumbuhan dimana terdapat mikroorganisme yang hidup bersimbiosa di sekitar akar (Arsil, 2010). Hal ini dapat dibuktikan dari efisiensi penyisihan yang rendah pada bak kontrol (tanpa tanaman), berada pada rentang $31,66-54,93 \%$. Nilai COD effluen limbah cair kelapa sawit mengalami penurunan yang menunjukkan bahwa mikroorganimse/bakteri pendegradasi yang bersimbiosis dengan akar tanaman Typa latifolia mampu menguraikan bahan cemaran organik dalam limbah. Semakin banyak dan dalam jaringan akar dalam tanah, semakin luas zona rhizosphere yang tercipta, sehingga dapat menyerap material organik yang terdapat dalam limbah cair pabrik kelapa sawit dan berperan dalam proses penurunan konsentrasi COD.

Seperti penelitian yang dilakukan Artiyani (2011) dalam penurunan kadar N Total dan $\mathrm{P}$ Total pada limbah cair tahu dengan tanaman Hydrilla verticillata dengan variasi kerapatan tanaman $70 \mathrm{mg} / \mathrm{cm}^{2} ; 80 \mathrm{mg} / \mathrm{cm}^{2}$; dan $90 \mathrm{mg} / \mathrm{cm}^{2}$ didapat bahwa hasil Hydrilla verticillata mampu menurunkan konsentrasi tertinggi pada kerapatan tanaman $90 \mathrm{mg} / \mathrm{cm}^{2}$. Hal yang sama juga terjadi pada penelitian ini, semakin tinggi kerapatan tanaman semakin tinggi pula efisiensi penyisihan pencemar COD. Penurunan kadar COD pada limbah cair yang diberi perlakuan Typha latifolia lebih besar dari yang tidak menggunakan Typha latifolia.

\section{Pengaruh Kadar limbah}

Pada Gambar 3. terlihat bahwa semakin rendah kadar limbah semakin tinggi penyisihan COD dari limbah cair kelapa sawit. Dengan sedikit kandungan organik yang akan diuraikan, kemampuan reaktor untuk mendukung penyerapan akar semakin meningkat. Bahan organik yang terdapat 
didalam air limbah akan dirombak oleh mikroorganisme menjadi senyawa lebih sederhana dan akan dimanfaatkan oleh tumbuhan sebagai nutrien, sedangkan sistem perakaran tumbuhan air akan menghasilkan oksigen yang dapat digunakan sebagai sumber energi/katalis untuk rangkaian proses metabolisme bagi kehidupan mikroorganisme (Hidayat \& Wahyu, 2010).

Apabila bahan cemaran organik di dalam limbah sudah terurai oleh mikroorganisme/bakteri pendegradasi, jumlahnya akan semakin sedikit, oksigen yang dibutuhkan juga semakin sedikit sehingga nilai CODnya kecil (Ariningrum,dkk, 2009). Avlenda (2009) dalam penelitiannya yang mengolah BOD dan COD pada limbah cair pabrik kelapa sawit dengan menggunakan tanaman kangkung dan genjer dengan variasi kadar limbah 20\%, 40\% 60\%, dan $80 \%$ mendapatkan efisiensi penyisihan tertinggi pada kadar limbah 20\% dengan BOD 75,6\% dan COD $76,2 \%$ dengan tanaman genjer. Pada penelitian ini juga didapatkan efisiensi penyisihan BOD pada kadar limbah $20 \%$.

\section{Perbandingan Efluen Limbah Cair Pabrik Kelapa Sawit Dengan Baku Mutu Limbah Cair Pabrik Kelapa Sawit}

Hasil air olahan atau efluen yang telah didapatkan dari penelitian ini dibandingkan dengan baku mutu limbah cair pabrik kelapa sawit yaitu Keputusan Menteri Lingkungan Hidup No. 51 Tahun 1995. Perbandingan efluen dengan waktu tinggal 5 hari dan 9 hari dengan baku mutu limbah cair yang digunakan adalah pada Tabel 4 .

Pengujian efluen limbah cair waktu tinggal 5 hari dan 9 hari ada yang memenuhi dan ada yang tidak memenuhi baku mutu. Pada hari ke 5 didapatkan nilai efluen limbah cair masih di atas baku mutu. Sampel yang memenuhi baku mutu dan hasil paling efisien adalah variasi kadar limbah 20\%, pada kerapatan tanaman $1 \mathrm{~g} / \mathrm{cm}^{2}$ dengan waktu tinggal 9 hari. Pada tabel di atas menunjukkan semakin lama waktu tinggalnya, semakin rendah kadar limbah, dan semakin rapat tanaman di dalam reaktor maka semakin efektif penurunan konsentrasi CODnya. Semakin kecil nilai COD menunjukkan kualitas air limbah hasil pengolahan semakin baik.

Tabel 4. Perbandingan Efluen $\mathrm{H}_{5}$ dan $\mathrm{H}_{9}$ Dengan Baku Mutu

\begin{tabular}{|c|c|c|c|c|}
\hline \multirow{2}{*}{$\begin{array}{c}\text { Kadar } \\
\text { Limbah } \\
(\%)\end{array}$} & \multirow{2}{*}{$\begin{array}{c}\text { Kerapatan } \\
\text { Tanaman } \\
\left(\mathrm{g} / \mathrm{cm}^{2}\right)\end{array}$} & \multicolumn{2}{|c|}{$\begin{array}{l}\text { Hasil Uji Efluen } \\
\text { COD (mg/l) }\end{array}$} & \multirow[t]{2}{*}{ BMAL } \\
\hline & & H5 & H9 & \\
\hline \multirow{4}{*}{20} & 0 & 1600 & 1280 & 500 \\
\hline & 0,5 & 880 & 200 & 500 \\
\hline & 0,75 & 820 & $160 *$ & 500 \\
\hline & 1 & 720 & $80 *$ & 500 \\
\hline \multirow{4}{*}{60} & 0 & 1880 & 1620 & 500 \\
\hline & 0,5 & 1240 & 660 & 500 \\
\hline & 0,75 & 1160 & 600 & 500 \\
\hline & 1 & 1060 & $480 *$ & 500 \\
\hline \multirow{4}{*}{100} & 0 & 2720 & 2340 & 500 \\
\hline & 0,5 & 1680 & 1000 & 500 \\
\hline & 0,75 & 1620 & 860 & 500 \\
\hline & 1 & 1540 & 720 & 500 \\
\hline
\end{tabular}

BMAL = Baku mutu air limbah

*) = Nilai Efluen COD yang memenuhi BMAL

Tingginya efisiensi penyisihan COD dan terpenuhinya baku mutu limbah cair pabrik kelapa sawit sesuai dengan Keputusan Menteri Lingkungan Hidup No. 51 Tahun 1995, membuktikan bahwa metode fitoremediasi menggunakan Typha latifolia layak dijadikan sebagai salah satu alternatif pengolahan limbah cair pabrik kelapa sawit, khususnya untuk mengolah limbah cair pabrik kelapa sawit PT. Perkebunan Nusantara V-PKS Sei Buatan.

\section{SIMPULAN}

Efisiensi penyisihan parameter pencemar paling tinggi yaitu pada variasi kerapatan tanaman $1 \mathrm{~g} / \mathrm{cm}^{2}$, kadar limbah $20 \%$, dan pada waktu tinggal 9 hari dengan penurunan COD $97,18 \%$.

Variasi kerapatan tanaman memberikan pengaruh yang signifikan dalam penyisihan COD. Semakin rapat tanaman maka semakin tinggi efisiensi penyisihan parameter pencemar yang diolah. Efisiensi penyisihan terbaik BOD, COD, dan TSS diperoleh pada kerapatan tanaman $1 \mathrm{~g} / \mathrm{cm}^{2}$. 
Variasi kadar limbah sangat berpengaruh terhadap efisiensi penyisihan parameter pencemar. Semakin rendah kadar limbah maka semakin tinggi efisiensi penyisihan parameter pencemar yang diolah. Efisiensi penyisihan terbaik diperoleh pada kadar limbah $20 \%$

Variasi waktu tinggal memberikan pengaruh terhadap efisiensi penyisihan. Semakin lama waktu tinggal yang digunakan semakin tinggi penyisihan pencemar yaitu diperoleh pada waktu tinggal 9 hari, Hasil pengolahan limbah cair pabrik kelapa sawit dengan metode fitoremediasi menggunakan Typha latifolia yang memenuhi baku mutu limbah cair pabrik kelapa sawit berdasarkan Keputusan Menteri Lingkungan Hidup Nomor 51 Tahun 1995 untuk parameter COD, dan TSS adalah pada variasi kerapatan tanaman $1 \mathrm{~g} / \mathrm{cm}^{2}$, kadar limbah $20 \%$, dan dengan waktu tinggal 9 hari.

Tingginya efisiensi penyisihan parameter pencemar yang didapatkan dalam penelitian ini membuktikan bahwa metode fitoremediasi menggunakan Typha latifolia layak dijadikan sebagai salah satu alternatif pengolahan limbah cair pabrik kelapa sawit, khususnya untuk mengolah limbah cair pabrik kelapa sawit PT. Perkebunan Nusantara V-PKS Sei Buatan

\section{DAFTAR PUSTAKA}

Arsil, P. 2010. Pengolahan Limbah Cair Dari Industri Kecil Pengolahan Tahu Secara Biofiltrasi Mrnggunakan Enceng Gondok (Eichhornia crassipes (Mart.) Solms). Laboratorium Teknik Pertanian dan Laboratorium Ilmu Tanah, Fakultas Pertanian, Universitas Jenderal Soedirman

Artiyani, A. 2011. Penurunan Kadar NTotal Dan P-Total Pada Limbah Cair Tahu Dengan Metode Fitoremediasi Aliran Batch Dan Kontinyu Menggunakan Tanaman Hydrilla Verticillata. Jurnal Spectra No. 18 Vol. IX Juli 2011. Fakultas Teknik Sipil dan Perencanaan. Malang: Institut Teknologi Nasional.
Avlenda, E. 2009. Penggunaan Tanaman Kangkung (Ipomoea aquatic Forsk.) Dan Genjer (Limnocharis flava (L.) Buch.) Dalam Pengolahan Limbah Cair Pabrik Kelapa Sawit. Program Studi Biologi.

Azwir. 2006. Analisa Pencemaran Sungai Tapung Kiri oleh Limbah Industri Kelapa Sawit PT. Peputra Masterindodi Kabupaten Kampar. http://eprints.undip.ac.id.

Evasari, J. 2012. Pemanfaatan Lahan Basah Buatan Dengan Menggunakan Tanaman Typha Latifolia Untuk Mengelola Limbah Cair Domestik (Studi Kasus: Limbah Cair Kantin Fakultas Teknik Universitas Indonesia). Skirpsi Sarjana. Program Studi Teknik Lingkungan Universitas Indonesia. Depok.

Frislidia. 2013. Perkebunan sawit Riau terluas di Indonesia. http://www.antaranews.com/berita/38 2433/perkebunan-sawit-riau-terluasdi-indonesia. Tanggal Akses: 13 Desember 2013

Hidayah, E.N., dan W. Aditya. 2010 Potensi dan Pengaruh Tanaman pada Pengolahan Air Limbah Domestik dengan Sistem Constructed Wetland. Jurnal Ilmiah Teknik Lingkungan, vol 2 11-18. http://eprints.upnjatim.ac.id

Kementerian Lingkungan Hidup. 1995. Keputusan Menteri Lingkungan Hidup Nomor 51 Tahun 1995 tentang Baku Mutu Limbah Cair Bagi Kegiatan Industri.

Melithia,C. L.A. Jhonson, dan W. Amber. 1996. Ground Water Polution: In situ Biodegradation. Down loading, available at http:www. cee. vt.edu/ program_areas/ enviromental teach/gwprimer /group1 / ind /ex html.

Raharjo, P.N. 2009. Studi Banding Teknologi Pengolahan Limbah Cair Pabrik Kelapa Sawit. Jurnal Teknologi Lingkungan, vol 10(1), 0918. http://ejurnal.bppt.go.id. 